\title{
Relationships among critical success factors of knowledge management and organizational performance
}

\begin{abstract}
The main objective of this study is to find relationships among critical success factors of Knowledge Management (KM) include; organizational factors and KM processes with organizational performance. The research proposes that KM in the public sector is still in its infancy and has a long way to go in the KM journey. However, the study has identified a certain number of factors that are essential to the success of the KM initiative and program in the public sector. The study also explain current situation in terms of $\mathrm{KM}$ activities in the public sector in Iran and sustain the discussion about KM processes in the public sector. The result of this investigation could have significant implications for KM programs in public sector organizations in Iran. The paper describes and develops a framework of KM process in the public sector as well as recommendations to practitioners about planning and implementing KM programs and initiatives.
\end{abstract}

Keyword: Organizational factors; KM processes; Organizational performance 